1973 WPA erchaeology. Excerpt from Archaeological survey of northern Georgia. In In search of man: readings in archaeology, by Ernestene L. Green, pp. 53-58. Little, Brown, Boston.

1974a Reminiscences. Excerpts from Archaeological survey of northern Georgia. In A slice of life: readings in general anthropology, by Lionel A. Brown, pp. 251-259. Holt, Rinehart \& Winston, Sen Francisco.

1974b Review of Quichean civilization, by Robert Carmack. Hispanic American Historical Review 54: 165-166.

1975 Zacualpa, El Quiche, Guatemala: an ancient provincial center of the highland Maya. Tulane University, Middle American Research Institute, Publication 39. New Orleans.

1977 Review of The early Mesoamerican village, edited by Kent V. Flannery. American Antiquity 42: 656-659.

1978 Edith Bayles Ricketson, 1899-1976. American Antiquity 43:615-617.

MARGARET A. L. HARRISON

\title{
ADOLFO MOLINA ORANTES, 1915-1980
}

Dr. Adolfo Molina Orantes, a former Foreign Minister of Guatemala and a world-recognized figure in internetional law, was killed on Januery 31, 1980, in a fire and riot in the Spanish Embassy in Guatemala City. For those of us in Maya archaeology, Adolfo Moline will be remembered as a staunch supporter of the archaeological cause in his country. He served both the Harvard University (Altar de Sacrificios, Seibal) and the University of Pennsylvania (Tikal) archaeological projects as legal advisor and wise counselor. In so doing, he gave his time and energy unstintingly and without monetary compensation. In his last years he was President of the Academia de Geografía e Historía de Guatemala, an orgenization devoted to the furtherance of archaeological, geographical, and historical research in the country. We are saddened by his untimely and tragic death, and we know we will be joined in these sentiments by many of our colleagues. Although Adolfo Molina would have been the last to lay claim to professional archaeological affiliation, his service to the field was such that we would like to offer this modest tribute to it in these pages.

GORDON R. WILLEY and WILLIAM R. COE 